\title{
Experimental infection of twenty species of Indian marine crabs with white spot syndrome virus (WSSV)
}

\author{
A. S. Sahul Hameed*, G. Balasubramanian, S. Syed Musthaq, K. Yoganandhan \\ Department of Zoology, C. Abdul Hakeem College, Melvisharam 632 509, Vellore District, Tamil Nadu, India
}

\begin{abstract}
Twenty species of Indian marine crabs were experimentally infected with white spot syndrome virus (WSSV), via the oral route and intramuscular injection, to determine their viral susceptibility. We determined that 16 species (Calappa philargius, Charybdis annulata, C. lucifera, Doclea hybrida, Grapsus albolineatus, Halimede ochtodes, Liagore rubronaculata, Lithodes maja, Matuta miersi, Paradorippe granulata, Parthenope prensor, Philyra syndactyla, Podophthalmus vigil, Portunus sanquinolentus, Scylla serrata and Thalamita danae) were susceptible and 4 (Atergatis integerrimus, Charybdis natator, Demania splendida or Menippe rumphii) were refractive at $50 \mathrm{~d}$ postinfection (p.i.). The presence of WSSV in these crabs was confirmed by PCR tests, histology and bioassay. WSSV was found in the gill, heart, eyestalks, striated muscle and cephalothoraxic tissue. The 4 WSSV-refractive species represent potential reservoirs or carriers of WSSV.
\end{abstract}

KEY WORDS: WSSV $\cdot$ Penaeid shrimp $\cdot$ Marine crabs $\cdot$ PCR $\cdot$ Histology

\section{INTRODUCTION}

White spot disease (WSD) is a serious viral disease of marine shrimp characterized by white spots in the exoskeleton of infected Peneaus monodon (Chou et al. 1995, Wang et al. 1995, Lightner 1996). The causative agent is white spot syndrome virus (WSSV), which is responsible for high mortalities and severe losses to global shrimp aquaculture (Lightner 1996). The losses in India alone have been estimated at several million dollars per year (Anonymous 1996). WSSV has been isolated and characterized from 2 species of shrimp found in India, $P$. indicus and $P$. monodon (Sahul Hameed et al. 1998). WSSV targets organs originating from embryonic mesoderm and ectoderm, producing hypertrophied nuclei with intranuclear inclusion bodies (Wang et al. 1995, Chang et al. 1996, Yoganandhan et al. 2003).

WSSV has a wide host range that includes more than 40 species of crabs, copepods and other arthropods
(Cai et al. 1995, Chang et al. 1998, Lightner et al. 1998, Wang et al. 1998). It naturally infects all the major species of cultivated penaeid shrimp (Wongteerasupaya et al. 1995, Lo et al. 1996, Flegel 1997, Lightner et al. 1997, Nunan et al. 1998, Sahul Hameed et al. 1998). Both natural and experimental infections have been reported in caridean shrimp (Exopalaemon orientalis, Macrobrachium rosenbergii, $M$. idella and M. lamerrae; Chang et al. 1998, Peng et al. 1998, Wang et al. 1998, Sahul Hameed et al. 2000), crayfish (Cambarus clarki and Pacifastacus leniusculus; Huang et al. 2001, Jiravanichpaisal et al. 2001), wild crabs (Calappa lophos, Portunus sanguinolentus, Portunus pelagicus, Charybdis sp., Helice tridens and Scylla serrata; Chang et al. 1998, Kanchanaphum et al. 1998, Chen et al. 2000, Corbel et al. 2001), wild lobsters (Scyllarus arctus and Panulirus sp.; Chang et al. 1998), and planktonic copepods and pupae of an Ephydridae insect (Wang et al. 1998). Experimental WSSV infection has been demonstrated in freshwater crabs 
(Paratelphusa hydrodomous and Paratelphusa pulvinata), and Artemia sp. (Sahul Hameed et al. 2001, 2002). The aim of this study was to investigate the effects of experimentally induced WSSV infection (per os and intramuscular injection) on 20 species of Indian marine crabs.

\section{MATERIALS AND METHODS}

Collection and maintenance of experimental animals. Twenty species of marine crab (Atergatis integerrimus, Calappa philargius, Charybdis annulata, Charybdis lucifera, Charybdis natator, Demania splendida, Doclea hybrida, Grapsus albolineatus, Halimede ochtodes, Liagore rubronaculata, Lithodes maja, Matuta miersi, Menippe rumphii, Paradorippe granulata, Parthenope prensor, Philyra syndactyla, Podophthalmus vigil, Portunus sanquinolentus, Scylla serrata and Thalamita danae) were collected from fish-landing centers at Chennai along the east coast of India. Taxonomic identification was based on the works of Alcock (1900) and Jayabaskaran et al. (2000). The crabs (20 to $50 \mathrm{~g}$ avg. weight) were transported to the laboratory and acclimated in separate $500 \mathrm{l}$ aquaria ( $20 \mathrm{crabs}$ of the same species per aquarium, 30 to $34 \mathrm{ppt}, 27$ to $30^{\circ} \mathrm{C}$ ) for $5 \mathrm{~d}$ prior to the onset of study. They were fed minced fresh fish ad lib. Five of each species were randomly selected and screened for WSSV by PCR using the primers designed by Takahashi et al. (1996). Saltwater was pumped from the adjacent sea and allowed to sediment, thus removing sand and other particulate matter before use.

Preparation of viral inoculum. WSSV-infected Penaeus monodon with prominent white spots were collected from farms located near Nellore, India. Cephalothoraxic tissues (including gills) were homogenized in NaCl-Tris-EDTA (NTE) buffer $(0.2 \mathrm{M} \mathrm{NaCl}$, $0.02 \mathrm{M}$ Tris-HCl and 0.02 EDTA, pH 7.4) (10\% suspension) and centrifuged at $3000 \times g\left(20 \mathrm{~min}, 4^{\circ} \mathrm{C}\right)$. The supernatant was removed and centrifuged at $8000 \times g$ (30 $\mathrm{min}, 4^{\circ} \mathrm{C}$ ). The resulting supernatant was then passed through a $0.4 \mu \mathrm{m}$ filter and the filtrate stored at $-20^{\circ} \mathrm{C}$. Prior to storage, the total protein content of the filtrate was determined by the method of Lowry et al. (1951), and WSSV presence was confirmed by PCR using primers designed by Takahashi et al. (1996).

Infectivity experiments. The pathogenic effects of WSSV to the 20 crab species was tested by feeding them WSSV-infected shrimp tissue, or by intramuscular injection of the viral inoculum described above. For injection tests, each crab species (10 per tank) was challenged by injecting the viral inoculum $(300 \mu \mathrm{g}$ of total protein per crab, diluted to $50 \mu \mathrm{l}$ with NTE buffer) into the soft tissue at the base of the swimming legs. Negative-control crabs were injected with a WSSVnegative tissue inoculum (300 $\mathrm{\mu g}$ of total protein per $\mathrm{crab}$ ) prepared from uninfected shrimp. For oral infection, 10 crabs per species were placed in a $100 \mathrm{l}$ aquarium and starved for $24 \mathrm{~h}$ before being fed WSSVinfected shrimp tissue at a rate of $5 \%$ body weight $\mathrm{d}^{-1}$. The daily ration was divided into 3 portions that were fed at $8 \mathrm{~h}$ intervals for $3 \mathrm{~d}$, after which the crabs were fed minced fresh fish. The control group was fed uninfected shrimp tissue followed by minced fish. The experimental crabs were examined twice per day for gross signs of disease, and daily mortality was recorded. All of the negative-control and treatmentgroup experiments, either exposed per os or by injection, were done in replicate.

Confirmation of WSSV infection by PCR. WSSVinfection status of the crabs was confirmed by PCR analysis of ectodermal and mesodermal organs for the presence of lesions characteristic of WSD (Lightner 1996). Template DNA for PCR tests was extracted from eyestalks, heart, gills, cephalothoraxic tissue or muscle following the method of Lo et al. (1996). Organs $(20 \mathrm{mg}$ per organ) to be extracted were cut and homogenized separately in NTE buffer. Each homogenate was centrifuged at $3000 \times g\left(4^{\circ} \mathrm{C}\right)$ and the resulting supernatant $(200 \mu \mathrm{l})$ then transferred to another centrifuge tube together with $600 \mu \mathrm{l}$ of digestion buffer $(100 \mathrm{mM} \mathrm{NaCl}$, $10 \mathrm{mM}$ Tris $\mathrm{HCl}, \mathrm{pH}$ 8.0, $50 \mathrm{mM}$ EDTA, pH 8.0, $0.5 \%$ sodium dodecyl sulfate, $0.1 \mathrm{mg} \mathrm{ml}^{-1}$ proteinase $\mathrm{K})$. After a $2 \mathrm{~h}$ incubation $\left(65^{\circ} \mathrm{C}\right)$, the digest was deproteinized by successive phenol/chloroform/isoamyl alcohol extractions, the DNA ethanol precipitated and dried. The dried DNA pellet was resuspended in $10 \mu \mathrm{l}$ of TE buffer (Tris-HCl 100 mM, pH 8.0, 10 mM EDTA, $\mathrm{pH}$ 8.0). Single-step PCR and nested-PCR tests were used to confirm the WSSV-infection status. For singlestep PCR, primers were designed to amplify a $426 \mathrm{bp}$ sequence of WSSV DNA based upon the genomic sequence of van Hulten et al. (2001). The primer sequences were: $5^{\prime}$-TTC TTC TTG ATT TCG TCC-3' and 5 '-AAT TCG TGG AGA GAG GTC C-3'. The reaction mixture contained $2 \mu \mathrm{l}$ of template DNA, $1 \mu \mathrm{M}$ of each primer, $200 \mu \mathrm{M}$ of deoxynucleotide triphosphate and $1.25 \mathrm{U}$ of Taq DNA polymerase in PCR buffers supplied with a commercially available kit (Finnzymes). The PCR protocol comprised 35 cycles of $0.5 \mathrm{~min}$ at $95^{\circ} \mathrm{C}, 1 \mathrm{~min}$ at $55^{\circ} \mathrm{C}$ and $1 \mathrm{~min}$ at $72^{\circ} \mathrm{C}$, with a final extension of $5 \mathrm{~min}$ at $72^{\circ} \mathrm{C}$. For the nested PCR, the internal primers for a $200 \mathrm{bp}$ fragment were $5^{\prime}$-ATC TCT ACC GTC ACA GCC C-3' and 5'-GAA GAT TTA ATG TCC TTG CTC G-3' (Yoganandhan et al. 2003). PCR products were analyzed by electrophoresis using $1 \%$ agarose gels stained with ethidium bromide and visualized by ultraviolet transillumination. 
Table 1. Cumulative percent mortality of Indian crabs at different time intervals after inoculation (intramuscular injection or oral route) with white spot syndrome virus (WSSV), and results of PCR analysis. Histology was positive in all cases

\begin{tabular}{|c|c|c|c|c|c|c|c|}
\hline \multirow[t]{2}{*}{ Species } & \multirow{2}{*}{$\begin{array}{c}\text { Days to } 100 \% \\
\text { mortality by } \\
\text { injection }\end{array}$} & \multirow{2}{*}{$\begin{array}{l}\% \text { mortality } \\
\text { by oral route } \\
(30 \mathrm{~d})\end{array}$} & \multicolumn{5}{|c|}{ PCR test } \\
\hline & & & G & HT & $\mathrm{H}$ & M & $\mathrm{E}$ \\
\hline Atergatis integerrimus & None (30) & 0 & ++ & ++ & ++ & + & + \\
\hline Calappa philargius & 4.3 & 70 & ++ & ++ & + & + & + \\
\hline Charybdis annulata & 3.5 & 90 & + & ++ & + & ++ & + \\
\hline Charybdis lucifera & 4.0 & 80 & + & ++ & ++ & + & + \\
\hline Charybdis natator & None (30) & 0 & ++ & ++ & + & + & + \\
\hline Demania splendia & None (30) & 0 & ++ & ++ & ++ & + & + \\
\hline Doclea hybrida & 10.0 & 60 & ++ & ++ & ++ & ++ & + \\
\hline Grapsus albolineatus & 2.0 & 90 & ++ & ++ & ++ & ++ & + \\
\hline Halimede ochtodes & 10.0 & 70 & ++ & ++ & ++ & ++ & ++ \\
\hline Liagore rubronaculata & 10.0 & 60 & ++ & ++ & ++ & + & + \\
\hline Lithodes maja & 3.5 & 80 & ++ & ++ & ++ & + & ++ \\
\hline Matura miersi & 4.0 & 80 & ++ & ++ & ++ & + & ++ \\
\hline Menippe rumphii & None (30) & 0 & + & + & + & + & ++ \\
\hline Paradorippe granulata & 4.3 & 70 & ++ & ++ & ++ & + & ++ \\
\hline Parthenope prensor & 4.3 & 80 & ++ & ++ & ++ & + & + \\
\hline Philyra syndactyla & 10.0 & 70 & ++ & ++ & ++ & + & ++ \\
\hline Podophthalmus vigil & 4.0 & 80 & ++ & ++ & ++ & + & + \\
\hline Portunus sanquinolentus & 5.0 & 70 & ++ & ++ & ++ & ++ & ++ \\
\hline Scylla serrata & 4.0 & 90 & ++ & ++ & ++ & ++ & ++ \\
\hline Thalamita danae & 6.0 & 70 & ++ & ++ & ++ & ++ & ++ \\
\hline
\end{tabular}

lucifera, Grapsus albolineatus, and Parthenope prensor) displayed autotomy, detaching their legs segment by segment before reaching the moribund stage. No gross signs of disease were observed in Atergatis integerrimus, Charybdis natator, Demania splendida or Menippe rumphii.

All of the challenged crabs, including those without gross signs of WSD, were 1-step PCR-positive for WSSV, but not for all of the organs tested (Table 1). However, all organs were WSSV-positive by nested PCR (Table 1). No WSSV-positive results were obtained for the negative control groups by PCR.

Histological examination of the experimentally challenged crabs revealed virus-infected cells characterized by basophilic intranuclear inclusions in tissues of ectodermal and mesodermal origin (gill tissue, striated muscle, eyestalks, and heart). However, the number of cells with hypertrophied nuclei was lower, or they were absent, in tissues of crabs showing no signs of WSD (i.e. Atergatis

Histology. Dissected organs were preserved in Davidson's fixative for $48 \mathrm{~h}$ and then transferred to $70 \%$ alcohol following the methods of Bell \& Lightner (1988). Sections (4 to $5 \mu \mathrm{m}$ thick) were stained with hematoxylin and eosin and observed by light microscopy.

\section{RESULTS AND DISCUSSION}

Cumulative percent mortality results (Table 1) revealed that WSSV was pathogenic to 16 of the 20 marine crab species, both through intramuscular injection and per os. A mortality of $100 \%$ was observed in these challenged groups at $10 \mathrm{~d}$ post-injection (p.i.), but the onset time and extent varied with species. Oral challenge caused mortality ranging from 60 to $90 \%$ at $30 \mathrm{~d}$ p.i. No mortality was observed in the negative control groups of both oral and intramuscular routes. To confirm WSSV infection, hemolymph from the experimentally infected crabs was intramuscularly injected into marine shrimp, which displayed similar gross signs of disease and severe mortality.

Gross signs of WSSV infection in the crabs included lethargy, reduced feed consumption, an initial dark and pinkish color on the dorsal sides, and a pale appearance at the time of morbidity. White spots in the cuticle were not observed. Some species (Charybdis integerrimus, Charybdis natator, Demania splendida and Menippe rumphii), when compared to those with WSD.

WSSV has a wide host-range and is a highly pathogenic virus that is transmitted to cultured shrimp via contaminated water and ingestion of WSSV-infected animals (Supamattaya \& Boonyaratpalin 1996). Transmission is also possible through cohabitation of infected species with uninfected stocks in both the shrimp farming environment and the wild (Flegel 1997, Flegel \& Alday-Sanz 1998). Ingestion of WSSVinfected tissue by shrimp and crabs is probably one of the principal infection routes of this virus, in both natural and farm environments.

The mortality data, together with PCR tests and histological observations, confirmed that all the marine crabs in this study may act as carriers of WSSV. Thus, they should not be used as raw feed materials for pondreared shrimp or brood-stock. This coincides with a previous recommendation made by Lo \& Kou (1998) to avoid using the marine crabs Charybdis feriatus and Portunus sanguinolentu as shrimp-feed additives or components.

Based on the present results, WSSV infection in marine crabs can be classified into 3 types. Type 1 is an acute infection with high mortality starting at $2 \mathrm{~d}$ p.i. and ending with $100 \%$ mortality at $5 \mathrm{~d}$ p.i. These crabs 
contain large numbers of infected cells with hypertrophied nuclei (i.e. Calappa philargius, Charybdis annulata, Charybdis lucifera, Grapsus albolineatus, Lithodes maja, Matuta miersi, Paradorippe granulata, Parthenope prensor, Podophthalmus vigil, Portunus sanquinolentus, Scylla serrata and Thalamita danae). Type 2 is a subacute infection with mortality starting at $5 \mathrm{~d}$ p.i. and ending with $100 \%$ mortality at $10 \mathrm{~d}$ p.i. These crabs display moderate numbers of infected cells (i.e. Doclea hybrida, Halimede ochtodes, Liagore rubronaculata and Philyra syndactyla). Type 3 infections are characterized by no mortality, but crabs are WSSV-PCR positive, with few or no infected cells seen by routine histology (i.e. Atergatis integerrimus, Charybdis natator, Demania splendida and Menippe rumphii). These different responses suggest that WSSV is species-specific, and other studies have also shown differences in WSSV pathogenicity. For example, Macrobrachium idella and $M$. lamerrae are susceptible, whereas M. rosenbergii is resistant (Sahul Hameed et al. 2000). Experimentally challenged Cancer maenas and Cancer mediterraneus show no signs of WSD (Shi 2000, Corbel et al. 2001), but Corbel et al. (2001) did not carry out tests to determine the presence of WSSV in survivors. In our experiments, the species with Type 3 infections survived for more than $50 \mathrm{~d}$, even though PCR results, histopathology, and hemolymph bioassay confirmed the presence of WSSV. Further work should be carried out to determine the mechanism of their resistance to WSD.

Acknowledgements. The authors thank the management of C. Abdul Hakeem College for providing the facilities to carry out this work. The cooperation of Dr. R. B. Narayanan, Centre for Biotechnology, Anna University, Chennai, to carry out this work is gratefully acknowledged. The authors also thank Mr. M. Kathirvel, principal scientist, Central Institute of Brackishwater Aquaculture for identification of the marine crabs used in this study. The financial assistance of the Department of Ocean Development, Government of India, New Delhi to carry out this work is acknowledged.

\section{LITERATURE CITED}

Alcock A (1900) Materials for the Carcinological fauna of India, No 5. The Branchyura Priniginea or Dromiacea. J Asiat Soc Beng 68:123-169

Anonymous (1996) Report of marine products export development agency. In: The Hindu, June 4, p 17

Bell TA, Lightner DV (1988) A handbook of normal penaeid shrimp histology. World Aquaculture Society, Baton Rouge, LA

Cai S, Huang J, Wang C, Song X, Sun X, Yu J, Zhang Y, Yang C (1995) Epidermiological studies on the explosive epidermic disease of prawn in 1993-1994. J Fish China 19: 112-117

Chang PS, Lo CF, Wang YF, Kou GH (1996) Identification of white spot syndrome associated baculovirus WSBV target organs in the shrimp Peneaus monodon by in situ hybridization. Dis Aquat Org 27:131-139

Chang PS, Chen HC, Wand YC (1998) Detection of white spot syndrome associated baculovirus WSBV in experimentally infected wild shrimps, crabs and lobsters by in situ hybridization. Aquaculture 164:23-242

Chen LL, Lo CF, Chiu YL, Chang CF, Kou GH (2000) Natural and experimental infection of white spot syndrome virus WSSV in benthic larvae of mud crab Scylla serrata. Dis Aquat Org 40:157-161

Chou HY, Huang CY, Wang CH, Chiang HC, Lo CF (1995) Pathogenicity of a baculovirus infection causing white spot syndrome in cultured penaeid shrimp in Taiwan. Dis Aquat Org 23:165-173

Corbel V, Zuprizal Z, Shi C, Huang I, Sumartono, Arcier JM Bonami JR (2001) Experimental infection of European crustaceans with white spot syndrome virus (WSSV). J Fish Dis 24:377-382

Flegel TW (1997) Special tropic review: major viral disease of the black tiger prawn Penaeus monodon in Thailand. World J Microbiol Biotechnol 13:433-442

Flegel TW, Alday-Sanz V (1998) The crisis in Asian shrimp aquaculture: current status and future needs. J Appl Ichthyol 14:269-273

Huang C, Zhang L, Zhang J, Xiao L, Wu Q, Chen D, Li JKK (2001) Purification and characterization of white spot syndrome virus (WSSV) produced in an alternative host: cray fish Cambarus clarkii. Virus Res 76:115-125

Jayabaskaran R, Ajimal khans, Ramaiyan V (2000) Brachyuran crabs of Gulf of Mannar. Centre of Advanced Study in Marine Biology, Annamalai University, Parangipettai

Jiravanichpaisal P, Bangyeekhun E, Soderhall K, Soderhall I (2001) Experimental infection of white spot syndrome in freshwater cray fish Pacifastacus leniusculus. Dis Aquat Org 47:151-157

Kanchanaphum P, Wongteerasupaya C, Sitidilokratana N, Boonsaeng V, Panyim S, Tassanakajon A, Withyachumnarnkul B, Felgel TW (1998) Experimental transmission of white spot syndrome virus WSSV from crabs to shrimp Penaeus monodon. Dis Aquat Org 34:1-7

Lightner DV (1996) A handbook of pathology and diagnostic procedures for diseases of penaeid shrimp. World Aquaculture Society, Baton Rouge, LA

Lightner DV, Redman RM, Poulos BT, Nunan LM, Mari JL, Hasson KW, Bonami JR (1997) Taura syndrome etiology, pathology, hosts and geographic distribution, and detection methods. In: New approaches to viral diseases of aquatic animals. National Research Institute of Aquaculture, Nansei Mie, Japan, p 190-205

Lightner DV, Hasson KW, White BL, Redman RM (1998) Experimental infection of white spot syndrome of western Hemisphere penaeid shrimp with Asian white spot syndrome virus and Asian yellow head virus. J Aquat Anim Health 10:271-281

Lo CF, Kou GH (1998) Virus-associated white spot syndrome of syndrome in Taiwan: a review. Fish Pathol 33:365-371

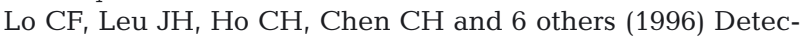
tion of baculovirus associated with white spot syndrome virus (WSSV) in penaeid shrimp using polymerase chain reaction. Dis Aquat Org 25:133-141

Lowry OH, Rosebrough NJ, Farr AL, Randall RJ (1951) Protein measurement with the folin phenol reagent. J Biol Chem 193:265-275

Nunan LM, Poulos BT, Lightner DV (1998) The detection of white spot syndrome virus (WSSV) and yellow head virus (YHV) in imported commodity shrimp aquaculture 160: $19-30$ 
Peng SE, Lo CF, Ho CH, Chang CF, Kou GH (1998) Detection of white spot baculovirus (WSBV) in giant freshwater prawn, Macrobrachium rosenbergii, using polymerase chain reaction. Aquaculture 164:253-262

Sahul Hameed AS, Anil Kumar M, Stephen Raj ML, Kunthala J (1998) Studies on the pathogenicity of systemic ectodermal and mesodermal baculovirus and its detection in shrimp by immunological methods. Aquaculture 160: $31-45$

Sahul Hameed AS, Xavier Charles M, Anilkumar M (2000) Tolerance of Macrobrachium rosenbergii to white spot syndrome virus. Aquaculture 183:207-213

Sahul Hameed AS, Yoganandhan K, Sathish S, Murugan V, Rasheed M, Kunthala Jayaraman (2001) Experimental pathogenicity of white spot syndrome virus (WSSV) in two freshwater crabs (Partelphusa hydrodomous and P. pulvinata). Aquaculture 201:179-186

Sahul Hameed AS, Murthi BLM, Rasheed M, Sathish S, Yoganandhan K, Murugan V, Kunthala Jayaraman (2002) An investigation of Artemia as a possible vector for white spot syndrome virus (WSSV) transmission to Penaeus indiCus. Aquaculture 204:1-10

Shi ZL (2000) Etude d'un virus Bacilliforme des de vetter Penaeidae (white spot syndrome virus WSSV): clonage, analysis partiel du genome et outills de diagnostics. $\mathrm{PhD}$ thesis, Universite des Science et Techniquesq du Languedoc, Mountpellier

Supamattaya K, Boonyaratpalin S (1996) The study of histopathology and cytopathlogical changes in black tiger

Editorial responsibility: Timothy Flegel,

Bangkok, Thailand shrimp Penaeus monodon caused by yellow head virus and red colour and white spot disease virus. J Sci Technol 18 1:17-33

Takahashi Y, Itami T, Maeda M, Suzuki N and 9 others (1996) Polyrmerase chain reaction (PCR) amplification of bacilliform virus (RV-PJ) DNA in Penaeus japonicus Bate and systemic ectodermal and mesodermal baculovirus (SEMBV) DNA in Penaeus monodon Fabricius. J Fish Dis 19:399-403

van Hulten MC, Witteveldt J, Peters S, Kloosterboer N and 5 others (2001) The white spot syndrome virus DNA genome sequence. Virology 167:233-241

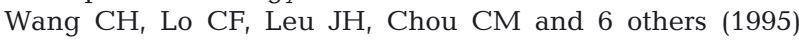
Purification and genomic analysis of baculovirus associated with white spot syndrome WSBV of Penaeus monodon. Dis Aquat Org 23:239-242

Wang YC, Lo CH, Chang PS, Kou GH (1998) Experimental infection of white spot baculovirus in some cultured and wild decapods in Taiwan. Aquaculture 164:221-231

Wongteerasupaya C, Vickers JE, Sriurairatana S, Nash GL and 6 others (1995) A non-occluded systemic baculovirus that occurs in cells of ectodermal and mesodermal origin and causes high mortality in the black tiger prawn Penaeus monodon. Dis Aquat Org 21:77-96

Yoganandhan K, Sathish S, Murugan V, Narayanan RB, Sahul Hameed AS (2003) Screening the organs for early detection of white spot syndrome virus in penaeid shrimp by histopathology and PCR techniques. Aquaculture 215: $21-29$

Submitted: January 31, 2003; Accepted: July 31, 2003 Proofs received from author(s): September 22, 2003 